\title{
Unifocal and multifocal chronic non-bacterial osteomyelitis (CNO) in children
}

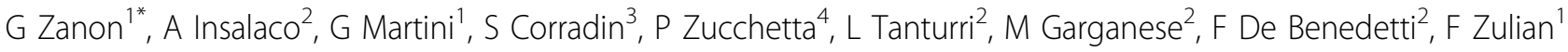 \\ From 18th Pediatric Rheumatology European Society (PReS) Congress \\ Bruges, Belgium. 14-18 September 2011
}

\section{Background}

Chronic non bacterial osteomyelitis (CNO) is a rare condition in children and little is known about its clinical assessment and course.

\section{Aim}

To describe the clinical characteristics and long-term outcome of pediatric patients with CNO.

\section{Methods}

We retrospectively evaluated patients with sterile bone inflammation, lasting longer than 6 month, referred to two tertiary care pediatric rheumatology units. Information on family history, clinical features at disease onset and course, laboratory and outcome were collected. A comparison between unifocal (UF-CNO) and multifocal course (MF-CNO), based on bone scintiscan result, was performed.

\section{Results}

29 CNO patients entered the study. Ten had UF-CNO, 19 had MF-CNO, mean age at disease onset 9,2 years (range 0,8-17), males (52\%). Disease duration at diagnosis was longer in pts with UF-CNO (11,1 vs 4,6 months). Localized bone pain was the leading symptom at onset in all patients; systemic symptoms, such as fever and fatigue, were more frequent in MF-CNO. 30\% presented associated skin disease and positive family history for autoimmune disease. At onset WBC normal, CRP was elevated in $38 \%$, ESR in $72 \%$, especially in MF-CNO. Scintiscan allowed us to identify multiple lesions in five patients with one-site symptoms. MF-CNO involve more frequently the lower limbs than the UF-CNO (18/ 19 vs 4/10, p 0,001). After three years follow up, $70 \%$ of

\footnotetext{
* Correspondence: giulia_zeta@libero.it

${ }^{1}$ Dept. of Pediatrics, University of Padua, Italy

Full list of author information is available at the end of the article
}

patients had no symptoms and $90 \%$ were off-therapy. UF-CNO developed complications, such as hyperostosis, vertebral collapse or limb dysmetry, significantly more often than MF-CNO (p 0,002).

\section{Conclusion}

UF-CNO and MF-CNO belong to the same spectrum but present different clinical features and outcome.

\section{Author details}

${ }^{1}$ Dept. of Pediatrics, University of Padua, Italy. ${ }^{2}$ RCCS Ospedale Pediatrico Bambino Gesù, Rome, Italy. ${ }^{3}$ Dept. of Radiology, University of Padua, Italy. ${ }^{4}$ Dept. of Nuclear Medicine, University of Padua, Italy.

Published: 14 September 2011

\section{doi:10.1186/1546-0096-9-S1-P32}

Cite this article as: Zanon et al:: Unifocal and multifocal chronic nonbacterial osteomyelitis (CNO) in children. Pediatric Rheumatology 20119 (Suppl 1):P32.

Submit your next manuscript to BioMed Central and take full advantage of:

- Convenient online submission

- Thorough peer review

- No space constraints or color figure charges

- Immediate publication on acceptance

- Inclusion in PubMed, CAS, Scopus and Google Scholar

- Research which is freely available for redistribution 